\title{
Relationship between physical activity times and intramuscular adipose tissue contents of the thigh muscle groups in younger and older men
}

Madoka Ogawa ( $\sim$ d0c0dem0.mad020@gmail.com )

Nippon Sport Science University

Noriko Tanaka

Nagoya University

Akito Yoshiko

Chukyo University

Yoshiharu Oshida

Minami Seikyo Hospital

Teruhiko Koike

Nagoya University

Hiroshi Akima

Nagoya University

\section{Research Article}

Keywords: age, muscle tissue, adipose tissue, thigh, physical activity

Posted Date: May 28th, 2021

DOI: https://doi.org/10.21203/rs.3.rs-566992/v1

License: (a) This work is licensed under a Creative Commons Attribution 4.0 International License. Read Full License 


\section{Abstract}

The present study aimed to investigate the effect of daily physical activities evaluated by steps and time on muscle tissue size and intramuscular adipose tissue (IntraMAT) content in the thigh muscle groups for younger and older men. Twenty younger ( $23.8 \pm 3.7$ years) and 20 older ( $70.7 \pm 5.6$ years) men participated in this study. We measured the muscle tissue cross-sectional area (CSA) and the IntraMAT content in the quadriceps femoris (QF), hamstrings (HM), hip adductors (AD), and total of mid-thigh by magnetic resonance imaging. We measured physical activity time using a triaxial accelerometer and determined four levels of physical activity depending on the metabolic equivalent (METs), e.g., sedentary ( $\leq 1.5 \mathrm{METs}$ ), light-intensity ( $\leq$ 2.9 METs), moderate-intensity (3.0 to $5.9 \mathrm{METs}$ ) and vigorous-intensity ( $\geq 6.0 \mathrm{METs}$ ). The muscle tissue CSA of AD was a significantly correlated with the time of vigorous-intensity activity in the older group $\left(r_{s}=0.446, P\right.$ $<0.05)$, but not in the younger group. The IntraMAT content of the three muscle groups (QF, AD, and HM) and the total thigh were significantly correlated with the time of moderate-intensity activity $\left(r_{s}=-0.625\right.$ to -0.489 , $P<0.05$, for all comparisons) in the younger group, but not in the older group. Our results suggest that the relationship of muscle tissue size and IntraMAT content with physical activity times is affected by age.

\section{Introduction}

Age-related decline of muscle strength is known to relate to muscle atrophy such as sarcopenia ${ }^{1,2}$. In addition, previous studies reported a loss of strength was caused by lower muscle quality such as increase of adipose tissue infiltration into the muscle ${ }^{1}$. Adipose tissues infiltrated in the muscle have defined two types based on their locations: intramuscular adipose tissue (IntraMAT) is defined as the visible extracellular adipose tissue and intermuscular adipose tissue is defined as the adipose tissue located between muscle groups ${ }^{3,4}$. The sum of IntraMAT and intermuscular adipose tissue is also known as IMAT ${ }^{4,5}$. The IntraMAT content in older individuals has twice or more than that of younger individuals in the thigh ${ }^{6}$. Further, larger amount of IMAT accumulation is known to induce glucose intolerance and insulin resistance ${ }^{7,8}$. One of epidemiological study showed that a larger muscle cross-sectional area (CSA), lower muscle quality, and higher muscle strength were respectively associated with a lower mortality risk ${ }^{9}$, suggesting that larger muscle size and lower IntraMAT content in older individuals would be desirable to reduce risk of mortality.

The distribution and amount of adipose tissue are strongly associated with physical activity levels ${ }^{10,11}$. A longitudinal monitoring study demonstrated that inactive twins had 54\% higher IMAT in the mid-thigh compared with their more active counterparts as a result of difference activity habits after 32 years ${ }^{12}$. Therefore, habitual physical activity is a crucial factor involved in the accumulation of adipose tissue into the muscle, without considering a genetic factor. Those previous findings suggest that importance of maintaining or increasing daily physical activity levels from the viewpoint of preventing the IntraMAT accumulation.

Adults with 18 to 65 years and older is recommended to keep moderate-intensity of physical activity (MPA: e.g., from 3.0 to $5.9 \mathrm{METs}$ ) for 150 to 300 min per a week, vigorous-intensity physical activity (VPA: e.g., $\geq 6.0 \mathrm{METs}$ ) for 75 to 150 min per a week, or combination of MPA and VPA by World Health Organization ${ }^{13}$. The maintenance of daily physical activity would link a key for the skeletal muscle components. A few studies have investigated the relationships between the time of physical activity and muscle mass. Significantly correlation 
was shown between both number of steps and 3 METs or higher of physical activity time and lower limb muscle mass in 75 years or older men and women. Interestingly, this correlation was not present for 3 METs or less of physical activity time ${ }^{14}$. As far as we know, one study investigated the relationship of physical activity time with IntraMAT; Kent-brown et al. (2003) reported a significant correlation between the content of IntraMAT in the lower leg and number of steps in older individuals. Using a triaxial accelerometer, daily physical activity levels can be evaluated based by number of steps, the time of activity with three level of intensity based on the metabolic equivalent of task (MET) and daily wasted calories. Adipose tissue, specifically lipids, is a more highly utilized energy source for light-intensity physical activity (LPA: e.g., $\leq 2.9$ METs) than for VPA ${ }^{15}$; therefore, LPA time may be inversely correlated with IntraMAT content in younger and older individuals.

The purpose of this study was to investigate the relationship of daily physical activities with muscle tissue size and IntraMAT content in the thigh muscle groups in younger and older men. Elucidating the relationship between physical activity and muscle tissue size and IntraMAT content in younger and older men is important for understanding the causes of muscle atrophy and IntraMAT accumulation with aging.

\section{Methods}

\section{Participants}

Twenty younger (age $24.5 \pm 4.8$ years; younger group) and 20 older (age $70.7 \pm 5.5$ years; older group) men volunteered to participate in the present study. Table 1 shows the physical characteristics of the subjects. The participants were widely recruited from healthy and non-obese (body mass index; BMI) $<25.0 \mathrm{~kg} / \mathrm{m}^{2}$ ) volunteers using a poster in a public facility. This experiment was conducted as a prospective study in 2016 and 2017. Before the experiment, the procedure, purposes, risks, and benefits associated with the study were explained, and written consent was obtained. The present study was approved by the Ethics Committee of the Research Center of Health, Physical Fitness and Sports (28-20) and the Graduate School of Medicine (20160254), Nagoya University, and was performed in accordance with the Declaration of Helsinki.

\section{Magnetic resonance imaging (MRI) acquisition}

The subjects were assessed with a 3.0 T whole-body MRI scanner (MAGNETOM Verio, Siemens Healthcare Diagnostics K.K., Tokyo, Japan). The subjects were placed in a supine position, and images of the thigh were acquired using a body coil. We defined the mid-thigh according to markers attached at the middle point between the greater trochanter and the lateral condyle of the femur. T1-weighted spin-echo sequence, transaxial images of the right thigh were collected with the following parameters: three-dimensional, TR $=604$ $\mathrm{ms} ; \mathrm{TE}=12 \mathrm{~ms}$; flip angle $=120$ degrees; optimized field of view $=256 \times 256 \mathrm{~mm}$; slice thickness $=10 \mathrm{~mm}$; and inter slice gap $=0 \mathrm{~mm}$. All participants were instructed to remain as still as possible throughout the imaging.

\section{Image analysis}

Medical Image Processing, Analysis and Visualization software (version 4.4.0; National Institutes of Health, Bethesda, MD) was used to analyze the images using a personal computer (OptiPlex 7050, Dell Inc., TX, USA). This procedure was essentially the same as that described previously ${ }^{3,6,16}$. The first step of the analysis was 
to correct for image heterogeneity caused by suboptimal radiofrequency coil uniformity or gradient-driven eddy currents using a well-established nonparametric nonuniform intensity normalization (N3) algorithm ${ }^{6,17}$. This step was essential for the subsequent analyses that assume homogenous signal intensity across images. The optimized image correction parameters were determined as follows: (end tolerance, 0.0001; maximum iterations, 100; signal threshold, 1; field distance, $25 \mathrm{~mm}$; subsampling factor, 4; kernel full width half maximum, 0.15; wiener filter noise, 0.01); the same parameters were applied to all images.

Second, we calculated the CSA of the IntraMAT and muscle tissue of the thigh using the previously described threshold method in the T1-weighted images ${ }^{6}$. Three regions of interest (ROIs) were isolated in the muscle and subcutaneous adipose tissue. Next, an auto-determined threshold was isolated at the base of the first peak of a bimodal histogram. The analysis was repeated three times for each image slice, and the average threshold value was used to classify tissue pixels. After carefully tracing the edge of each muscle, the following parameters were calculated: (1) the total number of pixels within the ROI, (2) the number of pixels with a signal intensity lower than the threshold value (muscle tissue), and (3) the number of pixels with a value higher than the threshold value. Subsequently, the muscle tissue CSA and IntraMAT CSA were calculated with the following equations:

Muscle tissue CSA $\left(\mathrm{cm}^{2}\right)=($ muscle tissue pixel number $) \times(\mathrm{FOV} / \text { matrix size })^{2}$

IntraMAT CSA $\left(\mathrm{cm}^{2}\right)=($ IntraMAT pixel number $) \times(\text { FOV } / \text { matrix size })^{2}$

in which FOV is the field of view.

The IntraMAT content was determined with the following equations 6 :

IntraMAT content $(\%)=\{$ IntraMAT CSA $/($ muscle tissue CSA + IntraMAT CSA $)\} \times 100$

For the muscle tissue and IntraMAT content, the quadriceps femoris (QF, i.e., the sum of the rectus femoris, vastus lateralis, vastus intermedius, and vastus medialis), hip adductors (AD, i.e., the sum of the adductor longus, adductor brevis, adductor magnus, sartorius, and gracilis) and hamstrings (HM, i.e., the sum of the biceps femoris short head, biceps femoris long head, semitendinosus, and semimembranosus) were evaluated as individual muscle groups. The sum of the muscle tissue CSAs of the QF, AD, and HM was calculated to determine the CSA of the total thigh.

\section{Physical activity level}

Physical activity was measured using an activity monitor equipped with a triaxial accelerometer (Active Style Pro HJA-750C, Omron Healthcare Co., Ltd., Japan). The algorithm of this activity monitor has been detailed in previous studies ${ }^{18,19}$. The relationship between METs measured by this activity monitor and energy expenditure measured by oxygen uptake and activity $(r=0.907, P<0.001)$ and walking $(r=0.961, P<0.001)$ during housework were examined, and it was confirmed that the intensity of physical activity could be estimated with high accuracy ${ }^{18,19}$. All participants were instructed to wear an activity monitor at the left waist throughout the entire day (except during bathing and sleeping) for 7 consecutive days. The participants were asked to continue their normal activities of daily living during the measurement period. The amount of time 
spent at each respective activity intensity was detected. Non-wearing time was defined as the sum of the time during which the activity count was below the detection threshold and was regarded as a zero count for 20 minutes or more ${ }^{20}$. A zero count in the activity monitor used in present study indicates that the METs estimated from the average value of the synthetic acceleration was less than 0.9. We used data that included measurements from 600 min or more per day ${ }^{20,21}$. Accelerometer estimates the intensity of physical activity times and defines sedentary time as $\leq 1.5 \mathrm{METs}$, LPA as $\leq 2.9$ METs, MPA as 3.0 to 5.9 METs and VPA as $\geq 6.0$ METs ${ }^{22,23}$. The CSV data files from the accelerometer were downloaded by Omron health management software BI-LINK for physical activity professional edition ver.2.0 and then the files were processed by custom software (Japan Physical Activity Research Platform Macro program for compiling data). All physical activity parameters were normalized per day.

\section{Statistical analysis}

All values are reported as the means and standard deviation. The Mann-Whitney $\mathrm{U}$ test was used to compare variables between the groups. The effect size $r$ was calculated. Spearman's rank correlation was used to determine the association between the muscle tissue CSA or IntraMAT content and physical activities. The level of significance was set at $P<0.05$. All statistical analyses were performed using IBM SPSS Statistics (version 24.0, IBM Japan, Tokyo, Japan).

\section{Results}

Table 1 shows the results of the physical characteristics of the subjects. Age, height, and BMI differed significantly between the groups $(P<0.001)$. The muscle tissue CSA of the total thigh, QF, and HM were significantly lower in the older group than in the younger group. Conversely, the muscle tissue CSA of the AD did not significantly differ between the groups. The \%body fat and IntraMAT contents of the thigh muscle groups were significantly higher in the older group than in the younger group.

Table 2 compares the physical activities (steps and times) between the younger and older groups. 4.0 to 5.9 METs and VPA times ( $\geq 6.0 \mathrm{METs}$ ) were significantly lower in the older group than in the younger group but not differ the steps, sedentary time, LPA and MPA times (Table 2).

Table 3 shows the relationships between the physical activities and the muscle tissue CSA in the three muscle groups (QF, AD, and HM) and the total thigh. In the older group, the muscle tissue CSA of the total thigh was a significantly positively correlated with $\geq 8.0 \mathrm{METs}$ of physical activity time $\left(r_{s}=0.452, P<0.05\right)$ but not with number of steps and other intensity of physical activity time. Furthermore, the muscle tissue CSA of AD was a significantly correlated with VPA $\left(r_{s}=0.446, P<0.05\right)$. In the younger group, the muscle tissue CSA of the total thigh and individual muscle groups were not significantly correlated with number of steps and physical activity times.

Table 4 shows the relationships between the number of steps and individual intensity of physical activity time and the IntraMAT content in the three muscle groups and the total thigh. In the younger group, the IntraMAT contents of the QF and AD, the total thigh were significantly inversely correlated with number of steps $\left(r_{s}=\right.$ -0.709 to $-0.481, P<0.05$, for all comparisons $)$ and 3.0 to $5.9 \mathrm{METs}\left(r_{s}=-0.625\right.$ to $-0.489, P<0.05$, for all 
comparisons). Conversely, there were no significant correlations between physical activities and IntraMAT contents in the three muscle groups and the total thigh for the older group $\left(r_{s}=-0.354\right.$ to 0.189 , n.s.).

Figure 1 shows the relationship between the MPA time and the IntraMAT contents in the three muscle groups and the total thigh. In the younger group, the IntraMAT contents of the three muscle groups and the total thigh were significantly inversely correlated with MPA time $\left(r_{s}=-0.625\right.$ to $-0.489, P<0.05$, for all comparisons). Conversely, there were no significant correlations between MPA time and IntraMAT contents in the three muscle groups and the total thigh for the older group $\left(r_{s}=-0.207\right.$ to 0.089 , n.s.).

\section{Discussion}

We investigate the relationship of daily physical activities evaluated by number of steps and time with muscle tissue size and IntraMAT content in the thigh muscle groups for younger and older men. MPA time (3.0 to 5.9 METs) was significantly inversely correlated with the IntraMAT contents of the three muscle groups ( $Q F, A D$, and HM) and the total thigh in the younger men, but not in the older men (Table 4). Furthermore, $\geq 8$ METs of the physical activity time was a significantly positively correlated with the muscle tissue size of the total thigh for the older group (Table 3). These results clearly indicated that specific intensities of physical activity would affect increase in muscle tissue size or decrease in IntraMAT content in younger and older individuals.

According to WHO guidelines, all adults would be recommended to perform MPA for 150 to 300 min or VPA for 75 to $150 \mathrm{~min}$, or some equivalent combination of MPA and VPA, per week for obtaining the health benefits ${ }^{13}$. There was no significant difference in number of steps, sedentary time, LPA and MPA times per day between the younger and older groups (Table 2); on the other hand, the older group had lower muscle tissue CSA and a higher IntraMAT content than the younger group (Table 1), which was consistent with the results of previous studies ${ }^{24-27}$. According to 5 years longitudinal study, the muscle CSA of the thigh decreased by $4.9 \pm 7.4 \%$ ( $1.0 \%$ per a year) whereas the IMAT CSA increased by $48.5 \pm 59.6 \%\left(9.7 \%\right.$ per a year) in older individuals ${ }^{1}$. It was reasonable age-related muscle atrophy and increased IntraMAT content exist in our older participants even if no significant difference in number of steps and physical activity times per day between two groups.

In the older group of this study, muscle tissue CSA was positive correlated with the $\geq 8$ METs of the physical activity time (Table 3). Those results were partially supported the results of a previous study that showed a relationship between the time of moderate and vigorous physical activity and the muscle mass of the lower limbs ${ }^{14}$. Collectively, 8 METs or higher physical activity might be beneficial to induce the muscle tissue size in older individuals. However, $\geq 8 \mathrm{METs}$ of the physical activity time was $2.3 \pm 8.1$ minutes in older group, and it is not clear to whether those are associated with muscle tissue size. On the other hands, in the younger group of this study, the number of steps and physical activity times were not significantly correlated with the muscle tissue CSA of the three muscle groups and total thigh, which was different result from that of the older group. It is generally observed that chronic walking and running does not induce lower limb muscle hypertrophy, especially in the thigh muscle, even in younger individuals ${ }^{28}$. Therefore, daily physical activity levels could be not affected to the muscle tissue size for younger individuals.

A notable finding in the present study is that the IntraMAT content in the total and each muscle group were significantly inversely correlated with MPA time, but not LPA and VPA times in the younger group and all 
physical activity times in the older group (Table 4 and figure 1). This result represents that between MPA time

and IntraMAT relationship was age-specific, which was consistent with the results of previous studies ${ }^{10,11}$. IntraMAT mainly reflects extramyocellular lipids $(E M C L)^{16}$, therefore, this result represent increase of MPA time may induce decreasing amount of EMCL in younger individuals. In the present study, IntraMAT content was a significantly inverse correlation with number of steps and physical activity times in the younger men, but not in the older men. Excessive IntraMAT accumulation could induce glucose intolerance and insulin resistance ${ }^{29,30}$. Thus, the present study suggests that MPA time could decrease IntraMAT in younger men; that is increased MPA time may prevent type 2 diabetes.

In the younger group, IntraMAT content in the total thigh, QF and AD were significant inverse correlation with 3.0 to 5.9 METs of the physical activity time, but HM had not correlation (Table 4). These results suggest that the relationship between physical activity times and IntraMAT may differ depend on the thigh muscle group. Akima et al. (2015) reported that IntraMAT content of HM was more than twice that of QF. The cause of the difference in the IntraMAT content between the thigh muscle groups has not been clarified, however, the physical activity times might be a factor that explains those difference. Further study is necessary to investigate whether there is a difference in the IntraMAT content change between the thigh muscle groups by the intervention of MPA in the younger individuals.

In the older group of the present study, number of steps and physical activity times were no significant correlation with IntraMAT contents in the total thigh and the three muscle groups (Table 4 and figure 1). To our knowledge, a few previous studies were examined the relationship between physical activity times and number of steps and IntraMAT content in the thigh. Akima et al. (2015) reported that there was no significant correlation between energy consumption evaluated by an accelerometer and IntraMAT content in the thigh for the older individuals. Furthermore, they investigated the IntraMAT content in the thigh as the dependent variable, and age, gender, BMI, subcutaneous adipose tissue and muscle CSAs per body weight, glycated hemoglobin, blood lipoprotein, adiponectin, and energy consumption as independent variables. As their result, only muscle CSA per body weight was selected as an independent variable with an inversely relationship with IntraMAT content in older individuals, and its contribution rate was 41\% (Akima et al. 2015). In the older group of the present study, the muscle tissue CSA was a significant inverse correlated with IntraMAT content in the QF and $\mathrm{HM}\left(r_{s}=-0.591\right.$ and $-0.530, P=0.006$ and 0.016$)$ as consisted with findings of Akima et al. (2015). Therefore, the previous and present studies suggests that muscle tissue size could associated with the IntraMAT accumulation in older individuals.

\section{Conclusion}

We found that the specific intensities of physical activity may affect development muscle tissue size or decrease in IntraMAT content in younger and older men. Increase MPA could be help decreases in IntraMAT content for younger men. Whereas increase $\geq 8$ METs of the physical activity may maintenance of muscle tissue size, and thereby prevent increases in IntraMAT content for older men.

\section{Abbreviations}




\begin{tabular}{ll} 
AD & hip adductors \\
\hline BMI & body mass index \\
\hline CSA & cross-sectional area \\
\hline HM & hamstrings \\
\hline LPA & light-intensity physical activity \\
\hline MET & metabolic equivalent of task \\
\hline MRI & magnetic resonance imaging \\
\hline MPA & moderate-intensity physical activity \\
\hline IMAT & intramuscular and intermuscular adipose tissues \\
\hline IntraMAT & intramuscular adipose tissue \\
\hline QF & quadriceps femoris \\
\hline VPA & vigorous-intensity physical activity
\end{tabular}

\section{Declarations}

\section{Founding}

The present study has received funding from a Grant-in-Aid for JSPS Research Fellow (to MO) and Grant-in-Aid for Young Scientists (B, 17K13087) (to NT).

\section{Conflicts of interest}

The authors of this manuscript declare no relationships with any companies whose products or services may be related to the subject matter of the manuscript.

\section{Authors' contributions}

$\mathrm{HA}$ and $\mathrm{MO}$ conceived and designed research. MO, TN, AY, TK and TO conducted experiments. HA provided knowledge for imaging analysis methods. MO analyzed imaging data. MO wrote the original manuscript. TN and AY contributed to writing the manuscript. HA edited the manuscript. The manuscript was reviewed and approved by all authors.

\section{Availability of data and material}

The data that support the findings of this study are available on request from the corresponding author (MO). The data are not publicly available due to their containing information that could compromise the privacy of research participants.

\section{Code availability}

Not applicable 


\section{Ethics approval}

The present study was approved by the Ethics Committee of the Research Center of Health, Physical Fitness and Sports (28-20) and the Graduate School of Medicine (2016-0254), Nagoya University, and was performed in accordance with the Declaration of Helsinki.

\section{Consent to participate}

Before the experiment, the procedure, purposes, risks, and benefits associated with the study were explained, and written consent was obtained by participate.

\section{References}

1 Delmonico, M. J. et al. Longitudinal study of muscle strength, quality, and adipose tissue infiltration. Am J Clin Nutr 90, 1579-1585, doi:10.3945/ajen.2009.28047 (2009).

2 Mitchell, W. K. et al. Sarcopenia, dynapenia, and the impact of advancing age on human skeletal muscle size and strength; a quantitative review. Front. Psycho/ 3, 260, doi:10.3389/fphys.2012.00260 (2012).

3 Yoshiko, A. et al. Effects of post-fracture non-weight-bearing immobilization on muscle atrophy, intramuscular and intermuscular adipose tissues in the thigh and calf. Skeletal Radiol, doi:10.1007/s00256018-2985-6 (2018).

4 Ogawa, M., Lester, R., Akima, H. \& Gorgey, A. S. Quantification of intermuscular and intramuscular adipose tissue using magnetic resonance imaging after neurodegenerative disorders. Neural Regen Res 12 , 2100-2105, doi:10.4103/1673-5374.221170 (2017).

5 Addison, O., Marcus, R. L., Lastayo, P. C. \& Ryan, A. S. Intermuscular fat: a review of the consequences and causes. Int J Endocrinol 2014, 309570, doi:10.1155/2014/309570 (2014).

6 Akima, H. et al. Skeletal muscle size is a major predictor of intramuscular fat content regardless of age. Eur J Appl Physiol 115, 1627-1635, doi:10.1007/s00421-015-3148-2 (2015).

7 Goodpaster, B. H. et al. Association between regional adipose tissue distribution and both type 2 diabetes and impaired glucose tolerance in elderly men and women. Diabetes Care 26, 372-379 (2003).

8 Boettcher, M. et al. Intermuscular adipose tissue (IMAT): association with other adipose tissue compartments and insulin sensitivity. JMR/29, 1340-1345, doi:10.1002/jmri.21754 (2009).

9 Reinders, I. et al. Muscle Quality and Myosteatosis: Novel Associations With Mortality Risk: The Age, Gene/Environment Susceptibility (AGES)-Reykjavik Study. Am J Epidemiol 183, 53-60, doi:10.1093/aje/kwv153 (2016).

10 Leskinen, T. et al. Leisure-time physical activity and high-risk fat: a longitudinal population-based twin study. Int J Obes 33, 1211-1218, doi:10.1038/ijo.2009.170 (2009). 
11 Kent-Braun, J. A., Ng, A. V. \& Young, K. Skeletal muscle contractile and noncontractile components in young and older women and men. J Appl Physiol (1985) 88, 662-668, doi:10.1152/jappl.2000.88.2.662 (2000).

12 Leskinen, T. et al. Physically active vs. inactive lifestyle, muscle properties, and glucose homeostasis in middle-aged and older twins. Age 35, 1917-1926, doi:10.1007/s11357-012-9486-7 (2013).

13 World Health Organization. Guidelines on physical activity and sedentary behaviour. Geneva: World Health Organization (2020).

14 Park, H., Park, S., Shephard, R. J. \& Aoyagi, Y. Yearlong physical activity and sarcopenia in older adults: the Nakanojo Study. Eur J Appl Physiol 109, 953-961, doi:10.1007/s00421-010-1424-8 (2010).

15 Romijn, J. A. et al. Regulation of endogenous fat and carbohydrate metabolism in relation to exercise intensity and duration. Am J Physio/ 265, E380-391, doi:10.1152/ajpendo.1993.265.3.E380 (1993).

16 Akima, H. et al. Intramuscular adipose tissue determined by T1-weighted MRI at 3T primarily reflects extramyocellular lipids. Magn Reson Imaging 34, 397-403, doi:10.1016/j.mri.2015.12.038 (2016).

17 Manini, T. M. et al. Reduced physical activity increases intermuscular adipose tissue in healthy young adults. Am J Clin Nutr 85, 377-384 (2007).

18 Oshima, Y. et al. Classifying household and locomotive activities using a triaxial accelerometer. Gait \& posture 31, 370-374, doi:10.1016/j.gaitpost.2010.01.005 (2010).

19 Ohkawara, K. et al. Real-time estimation of daily physical activity intensity by a triaxial accelerometer and a gravity-removal classification algorithm. Br J Nutr 105, 1681-1691, doi:10.1017/s0007114510005441 (2011).

20 Masse, L. C. et al. Accelerometer data reduction: a comparison of four reduction algorithms on select outcome variables. Med Sci Sports Exerc 37, S544-554 (2005).

21 Troiano, R. P. et al. Physical activity in the United States measured by accelerometer. Med Sci Sports Exerc 40, 181-188, doi:10.1249/mss.0b013e31815a51b3 (2008).

22 Gando, Y. et al. Light-intensity physical activity is associated with insulin resistance in elderly Japanese women independent of moderate-to vigorous-intensity physical activity. J Phys Act Health 11, 266-271, doi:10.1123/jpah.2012-0071 (2014).

23 Kurita, S. et al. Comparability of activity monitors used in Asian and Western-country studies for assessing free-living sedentary behaviour. PloS one 12, e0186523, doi:10.1371/journal.pone.0186523 (2017).

24 Overend, T. J., Cunningham, D. A., Paterson, D. H. \& Lefcoe, M. S. Thigh composition in young and elderly men determined by computed tomography. Clin Physio/ 12, 629-640 (1992).

25 Nakagawa, Y. et al. Age-related changes in intramyocellular lipid in humans by in vivo H-MR spectroscopy. Gerontology 53, 218-223, doi:10.1159/000100869 (2007). 
26 Hasson, C. J., Kent-Braun, J. A. \& Caldwell, G. E. Contractile and non-contractile tissue volume and distribution in ankle muscles of young and older adults. J Biomech 44, 2299-2306, doi:10.1016/j.jbiomech.2011.05.031 (2011).

27 Rossi, A. P. et al. Effects of body composition and adipose tissue distribution on respiratory function in elderly men and women: the health, aging, and body composition study. J Gerontol A Biol Sci Med Sci 66, 801808, doi:10.1093/gerona/glr05810.1093/gerona/glr059 (2011).

28 Ozaki, H., Loenneke, J. P., Thiebaud, R. S., Stager, J. M. \& Abe, T. Possibility of leg muscle hypertrophy by ambulation in older adults: a brief review. Clin Interv Aging 8, 369-375, doi:10.2147/cia.s43837 (2013).

29 Boettcher, M. et al. Intermuscular adipose tissue (IMAT): association with other adipose tissue compartments and insulin sensitivity. JMR/29, 1340-1345, doi:10.1002/jmri.21754 (2009).

30 Goodpaster, B. H., Thaete, F. L. \& Kelley, D. E. Thigh adipose tissue distribution is associated with insulin resistance in obesity and in type 2 diabetes mellitus. Am J Clin Nutr 71, 885-892 (2000).

\section{Tables}

Table 1. Subject characteristics

\begin{tabular}{|c|c|c|c|c|c|c|c|}
\hline & \multicolumn{3}{|c|}{ Younger group } & \multicolumn{2}{|c|}{ Older group } & \multirow{2}{*}{$\begin{array}{l}\text { Effect } \\
\text { size } r\end{array}$} \\
\hline & & $\begin{array}{r}\text { Mean } \\
\text { SD }\end{array}$ & & $95 \% \mathrm{CI}$ & $\begin{array}{l}\text { Mean } \\
\pm \text { SD }\end{array}$ & $95 \% \mathrm{CI}$ & \\
\hline \multicolumn{2}{|l|}{ Age (years) } & $\begin{array}{l}23.8 \\
3.7\end{array}$ & \pm & $\begin{array}{l}22.1, \\
25.5\end{array}$ & $\begin{array}{l}70.7 \pm \dagger \\
5.6\end{array}$ & $\begin{array}{l}68.1 \\
73.3\end{array}$ & 0.86 \\
\hline \multicolumn{2}{|l|}{ Height $(\mathrm{cm})$} & $\begin{array}{l}175.2 \\
6.3\end{array}$ & \pm & $\begin{array}{l}172.2, \\
178.1\end{array}$ & $\begin{array}{l}165.7 \pm \dagger \\
6.9\end{array}$ & $\begin{array}{l}162.4 \\
168.9\end{array}$ & 0.61 \\
\hline \multicolumn{2}{|l|}{ Body weight (kg) } & $\begin{array}{l}65.8 \\
8.7\end{array}$ & \pm & $\begin{array}{l}61.7 \\
69.9\end{array}$ & $\begin{array}{l}64.3 \pm \\
7.6\end{array}$ & $\begin{array}{l}60.7 \\
67.9\end{array}$ & 0.10 \\
\hline \multicolumn{2}{|l|}{ BMI $\left(\mathrm{kg} / \mathrm{m}^{2}\right)$} & $\begin{array}{l}21.4 \\
1.8\end{array}$ & \pm & $\begin{array}{l}20.5 \\
22.2\end{array}$ & $\begin{array}{l}23.4 \pm \dagger \\
2.1\end{array}$ & $\begin{array}{l}22.4 \\
24.4\end{array}$ & 0.46 \\
\hline \multicolumn{2}{|l|}{ \%body fat (\%) } & $\begin{array}{l}16.0 \\
3.7\end{array}$ & \pm & $\begin{array}{l}14.2 \\
17.7\end{array}$ & $\begin{array}{l}26.2 \pm \dagger \\
4.0\end{array}$ & $\begin{array}{l}24.3 \\
28.0\end{array}$ & 0.82 \\
\hline \multirow[t]{4}{*}{$\begin{array}{cc}\text { Muscle } & \text { tissue } \\
\text { CSA }\left(\mathrm{cm}^{2}\right)\end{array}$} & QF & $\begin{array}{l}73.0 \\
11.3\end{array}$ & \pm & $\begin{array}{l}67.8 \\
78.3\end{array}$ & $\begin{array}{l}54.1 \pm \dagger \\
8.2\end{array}$ & $\begin{array}{l}50.3 \\
58.0\end{array}$ & 0.77 \\
\hline & $\mathrm{AD}$ & $\begin{array}{l}42.1 \\
8.2\end{array}$ & \pm & $\begin{array}{l}38.3 \\
46.0\end{array}$ & $\begin{array}{l}37.0 \pm \\
9.4\end{array}$ & $\begin{array}{l}32.6 \\
41.4\end{array}$ & 0.26 \\
\hline & HM & $\begin{array}{l}26.7 \\
8.3\end{array}$ & \pm & $\begin{array}{l}22.8 \\
30.6\end{array}$ & $\begin{array}{l}17.7 \pm \dagger \\
4.6\end{array}$ & $\begin{array}{l}15.5 \\
19.8\end{array}$ & 0.64 \\
\hline & Total & $\begin{array}{l}141.8 \\
25.1\end{array}$ & \pm & $\begin{array}{l}130.1 \\
153.6\end{array}$ & $\begin{array}{l}108.8 \pm \dagger \\
0.2\end{array}$ & $\begin{array}{l}\text { 101.6, } \\
116.1\end{array}$ & 0.66 \\
\hline \multirow[t]{4}{*}{$\begin{array}{l}\text { IntraMAT content } \\
(\%)\end{array}$} & QF & $\begin{array}{l}6.3 \\
3.2\end{array}$ & \pm & $\begin{array}{l}4.8 \\
7.8\end{array}$ & $\begin{array}{l}10.0 \pm \dagger \\
2.9\end{array}$ & $\begin{array}{l}8.6 \\
11.3\end{array}$ & 0.57 \\
\hline & $\mathrm{AD}$ & 3.6 & \pm & $\begin{array}{l}5.8 \\
9.1\end{array}$ & $\begin{array}{l}13.2 \pm \dagger \\
4.5\end{array}$ & $\begin{array}{l}11.1 \\
15.4\end{array}$ & 0.60 \\
\hline & HM & $\begin{array}{l}13.1 \\
5.6\end{array}$ & \pm & $\begin{array}{l}10.5 \\
15.7\end{array}$ & $\begin{array}{l}25.6 \pm \dagger \\
6.3\end{array}$ & $\begin{array}{l}22.7 \\
28.6\end{array}$ & 0.73 \\
\hline & Total & $\begin{array}{l}7.9 \\
3.5\end{array}$ & \pm & $\begin{array}{l}6.3 \\
9.5\end{array}$ & $\begin{array}{l}14.0 \pm \dagger \\
3.7\end{array}$ & $\begin{array}{l}12.2 \\
15.7\end{array}$ & 0.68 \\
\hline
\end{tabular}


* $P<0.05 ; \dagger P<0.01$ vs. younger group, $B M I$ body mass index, $C S A$ cross-sectional area, IntraMAT intramuscular adipose tissue, $Q F$ quadriceps femoris, $A D$ hip adductors, $H M$ hamstrings.

Table 2. Comparison of physical activity time between the younger and older groups

\begin{tabular}{|c|c|c|c|c|c|}
\hline & \multicolumn{2}{|c|}{ Younger group } & \multicolumn{2}{|c|}{ Older group } & \multirow{2}{*}{$\begin{array}{l}\text { Effect } \\
\text { size } r\end{array}$} \\
\hline & $\begin{array}{c}\text { Mean } \pm \\
\text { SD }\end{array}$ & $95 \% \mathrm{CI}$ & $\begin{array}{l}\text { Mean } \\
\pm \text { SD } \\
\end{array}$ & $95 \% \mathrm{CI}$ & \\
\hline $\begin{array}{l}\text { Wear } \\
\text { time (min/day) }\end{array}$ & $\begin{array}{r}878.7 \pm \\
103.4\end{array}$ & $\begin{array}{l}830.3, \\
927.1\end{array}$ & $\begin{array}{l}871.5 \pm \\
62.8\end{array}$ & $842.1,900.9$ & 0.86 \\
\hline Steps (steps/day) & $\begin{array}{l}9155.8 \\
\pm 3182.7\end{array}$ & $\begin{array}{l}7666.3 \\
10645.3\end{array}$ & $\begin{array}{l}8365.3 \\
\pm \\
3828.1\end{array}$ & $\begin{array}{l}\text { 6573.7. } \\
10157.0\end{array}$ & 0.61 \\
\hline \multicolumn{6}{|l|}{$\begin{array}{l}\text { Physical activity } \\
\text { time (min/day) }\end{array}$} \\
\hline Sedentary time & $\begin{array}{l}541.1 \pm \\
115.9\end{array}$ & $\begin{array}{l}486.9 \\
595.4\end{array}$ & $\begin{array}{l}519.6 \pm \\
78.7\end{array}$ & $482.8,556.5$ & 0.11 \\
\hline$\leq 1.9$ METs & $\begin{array}{l}666.3 \pm \\
108.6\end{array}$ & $\begin{array}{l}615.5 \\
717.1\end{array}$ & $\begin{array}{l}630.4 \pm \\
67.7\end{array}$ & $598.8,662.1$ & 0.24 \\
\hline $\begin{array}{l}2.0 \text { to } 2.9 \\
\text { METs }\end{array}$ & $\begin{array}{l}132.5 \pm \\
41.8\end{array}$ & $\begin{array}{l}112.9 \\
152.0\end{array}$ & $\begin{array}{l}175.1 \pm \dagger \\
42.0\end{array}$ & $155.4,194.7$ & 0.47 \\
\hline LPA & $\begin{array}{l}798.8 \pm \\
102.1\end{array}$ & $\begin{array}{l}751.0 \\
846.6\end{array}$ & $\begin{array}{l}805.5 \pm \\
70.6\end{array}$ & $772.5,838.6$ & 0.01 \\
\hline $\begin{array}{l}3.0 \text { to } 3.9 \\
\text { METs }\end{array}$ & $\begin{array}{l}43.5 \pm \\
20.1\end{array}$ & $\begin{array}{l}35.3 \\
51.6\end{array}$ & $\begin{array}{l}40.9 \pm \\
16.0\end{array}$ & $33.4,48.4$ & 0.09 \\
\hline $\begin{array}{l}4.0 \text { to } 4.9 \\
\text { METs }\end{array}$ & $\begin{array}{l}23.3 \\
14.5\end{array}$ & $\begin{array}{l}16.5 \\
30.1\end{array}$ & $\begin{array}{l}14.0 \pm * \\
10.4\end{array}$ & $9.1,18.9$ & 0.33 \\
\hline $\begin{array}{l}5.0 \text { to } 5.9 \\
\text { METs }\end{array}$ & $6.9^{7.7^{ \pm}}$ & $\begin{array}{l}4.5 \\
10.9\end{array}$ & $15.4 \pm+$ & $0.3,14.7$ & 0.43 \\
\hline MPA & $\begin{array}{l}31.0 \pm \\
20.1\end{array}$ & $\begin{array}{l}21.6 \\
40.4\end{array}$ & $\begin{array}{l}21.5 \pm \\
22.0\end{array}$ & $11.2,31.9$ & 0.31 \\
\hline 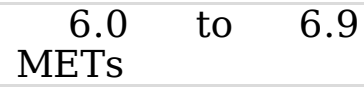 & $3.2^{2.0 \pm}$ & $3.5^{0.6}$ & $2.2^{0.9 \pm \dagger}$ & $-0.2,1.9$ & 0.56 \\
\hline $\begin{array}{r}7.0 \text { to } 7.9 \\
\text { METs }\end{array}$ & $1.6^{0.9 \pm}$ & $1.7^{0.1}$ & $0.8^{0.3 \pm \dagger}$ & $-0.1,0.7$ & 0.46 \\
\hline$\geq 8.0 \mathrm{METs}$ & $3.2^{2.4} \pm$ & $4.0^{0.9}$ & $8.1^{2.3 \pm \dagger}$ & $-1.5,6.1$ & 0.60 \\
\hline VPA & $7.3^{5.4} \pm$ & $8.8^{2.0}$ & $9.9^{3.5} \pm \dagger$ & $-1.2,8.2$ & 0.61 \\
\hline Total & $\begin{array}{l}835.2 \pm \\
98.4\end{array}$ & $\begin{array}{l}789.1 \\
881.3\end{array}$ & $\begin{array}{l}830.6 \pm \\
62.5\end{array}$ & $801.3,859.8$ & 0.07 \\
\hline
\end{tabular}

${ }^{*} P<0.05 ; \dagger P<0.01$ vs. younger group, $L P A$ light-intensity physical activity, MPA moderateintensity physical activity, VPA vigorous-intensity physical activity.

Table 3. Correlation coefficients between physical activities and muscle tissue cross-sectional area in the younger and older groups 


\begin{tabular}{|c|c|c|c|c|c|c|c|c|c|c|}
\hline \multirow{3}{*}{\multicolumn{3}{|c|}{ Characteristics }} & \multicolumn{8}{|c|}{ Muscle tissue CSA } \\
\hline & & & \multicolumn{4}{|c|}{ Younger group } & \multicolumn{4}{|c|}{ Older group } \\
\hline & & & $\mathrm{QF}$ & $\mathrm{AD}$ & $\mathrm{HM}$ & Total & $\mathrm{QF}$ & $\mathrm{AD}$ & $\mathrm{HM}$ & Total \\
\hline \multicolumn{3}{|c|}{$\begin{array}{l}\text { Steps } \\
\text { (steps/day) } \\
\text { Physical activity } \\
\text { time (min/dav) }\end{array}$} & 0.056 & -0.044 & -0.143 & 0.047 & 0.221 & 0.235 & 0.320 & 0.260 \\
\hline \multicolumn{3}{|c|}{ Sedentary time } & 0.152 & 0.138 & 0.406 & 0.186 & 0.050 & 0.286 & -0.137 & 0.110 \\
\hline \multicolumn{3}{|c|}{$\leq 1.9$ METs } & 0.102 & 0.180 & 0.265 & 0.155 & -0.045 & 0.137 & -0.156 & -0.014 \\
\hline \multirow{2}{*}{$\begin{array}{r}2.0 \\
\text { METs } \\
\text { LPA }\end{array}$} & to & 2.9 & -0.141 & -0.226 & $-0.448 *$ & -0.181 & -0.129 & -0.218 & 0.124 & -0.141 \\
\hline & & & 0.141 & 0.215 & 0.203 & 0.202 & -0.087 & 0.012 & -0.108 & -0.111 \\
\hline \multirow{4}{*}{$\begin{array}{r}3.0 \\
\text { METs } \\
4.0 \\
\text { METs } \\
5.0 \\
\text { METs } \\
\text { MPA }\end{array}$} & to & 3.9 & 0.125 & -0.046 & 0.021 & 0.132 & -0.171 & -0.057 & 0.233 & -0.156 \\
\hline & to & 4.9 & 0.114 & 0.094 & 0.090 & 0.182 & 0.063 & 0.308 & 0.050 & 0.158 \\
\hline & to & 5.9 & -0.023 & -0.026 & -0.057 & 0.029 & 0.227 & 0.290 & 0.178 & 0.282 \\
\hline & & & 0.047 & 0.059 & 0.041 & 0.126 & 0.123 & 0.289 & 0.085 & 0.183 \\
\hline \multirow{3}{*}{\multicolumn{2}{|c|}{$\begin{array}{l}6.0 \text { to } \\
\text { METs } \\
7.0 \text { to } \\
\text { METs } \\
\geq 8.0 \mathrm{METs}\end{array}$}} & 6.9 & 0.315 & 0.236 & 0.077 & 0.246 & 0.301 & 0.364 & 0.064 & 0.383 \\
\hline & & 7.9 & 0.414 & 0.131 & 0.170 & 0.238 & 0.391 & 0.344 & 0.286 & 0.386 \\
\hline & & & 0.372 & 0.124 & 0.102 & 0.208 & 0.421 & 0.331 & 0.348 & $0.452 *$ \\
\hline \multicolumn{3}{|c|}{ VPA } & 0.397 & 0.169 & 0.125 & 0.269 & 0.250 & $0.446^{*}$ & 0.102 & 0.400 \\
\hline \multicolumn{3}{|l|}{ Total } & 0.159 & 0.218 & 0.215 & 0.229 & 0.059 & 0.215 & -0.064 & 0.075 \\
\hline
\end{tabular}

$* P<0.05, \dagger P<0.01, Q F$ quadriceps femoris, $A D$ hip adductors, $H M$ hamstrings, $L P A$ light-intensity physical activity, MPA moderate-intensity physical activity, VPA vigorous-intensity physical activity.

Table 4. Correlation coefficients between physical activities and intramuscular adipose tissue (IntraMAT) contents in the younger and older groups 


\begin{tabular}{|c|c|c|c|c|c|c|c|c|}
\hline \multirow[t]{3}{*}{ Characteristics } & \multicolumn{8}{|c|}{ IntraMAT content (\%) } \\
\hline & \multicolumn{4}{|c|}{ Younger group } & \multicolumn{4}{|c|}{ Older group } \\
\hline & $\mathrm{QF}$ & $\mathrm{AD}$ & $\mathrm{HM}$ & Total & QF & $\mathrm{AD}$ & $\mathrm{HM}$ & Total \\
\hline $\begin{array}{l}\text { Steps } \\
\text { (steps/day) } \\
\text { Physical } \\
\text { activity } \\
\text { (min/dime }\end{array}$ & $-0.709 \dagger$ & $-0.481 *$ & -0.349 & $-0.569 \dagger$ & -0.084 & -0.215 & -0.060 & -0.104 \\
\hline Sedentary & -0.035 & 0.159 & -0.021 & 0.078 & -0.197 & -0.170 & -0.197 & -0.206 \\
\hline$\leq 1.9 \mathrm{METs}$ & -0.134 & 0.056 & 0.021 & 0.029 & -0.200 & -0.125 & -0.244 & -0.234 \\
\hline $\begin{array}{r}2.0 \text { to } 2.9 \\
\text { METs }\end{array}$ & $-0.500 *$ & -0.089 & 0.023 & -0.200 & 0.138 & 0.171 & 0.002 & 0.086 \\
\hline LPA & -0.296 & -0.060 & -0.018 & -0.101 & -0.214 & -0.081 & -0.290 & -0.245 \\
\hline $\begin{array}{c}3.0 \\
\text { METs }\end{array}$ to 3.9 & $-0.858 \dagger$ & $-0.645 \dagger$ & $-0.445^{*}$ & $-0.725 \dagger$ & -0.035 & -0.062 & 0.100 & 0.084 \\
\hline $\begin{array}{c}4.0 \\
\text { METs }\end{array}$ & $-0.646 \dagger$ & $-0.511 *$ & $-0.445^{*}$ & $-0.587 \dagger$ & -0.203 & -0.229 & 0.131 & -0.086 \\
\hline $\begin{array}{l}5.0 \text { to } 5.9 \\
\text { METs }\end{array}$ & $-0.584 \dagger$ & $-0.524^{*}$ & -0.400 & $-0.561 \dagger$ & -0.084 & -0.139 & 0.058 & -0.030 \\
\hline $\begin{array}{l}6.0 \text { to } 6.9 \\
\text { METs }\end{array}$ & -0.271 & -0.221 & -0.088 & -0.196 & -0.110 & -0.212 & 0.082 & -0.064 \\
\hline $\begin{array}{c}7.0 \\
\text { METs to } 7.9\end{array}$ & -0.141 & -0.020 & 0.083 & -0.022 & -0.162 & -0.354 & -0.065 & -0.141 \\
\hline$\geq 8.0 \mathrm{METs}$ & -0.026 & 0.093 & 0.212 & 0.101 & 0.126 & -0.131 & 0.189 & 0.143 \\
\hline VPA & -0.199 & -0.027 & 0.135 & -0.030 & -0.093 & -0.312 & 0.126 & -0.055 \\
\hline Total & -0.427 & -0.153 & -0.113 & -0.211 & -0.268 & -0.156 & -0.286 & -0.286 \\
\hline
\end{tabular}

$* P<0.05, \dagger P<0.01, Q F$ quadriceps femoris, $A D$ hip adductors, $H M$ hamstrings, $L P A$ light-intensity physical activity, VPA vigorous-intensity physical activity.

\section{Figures}




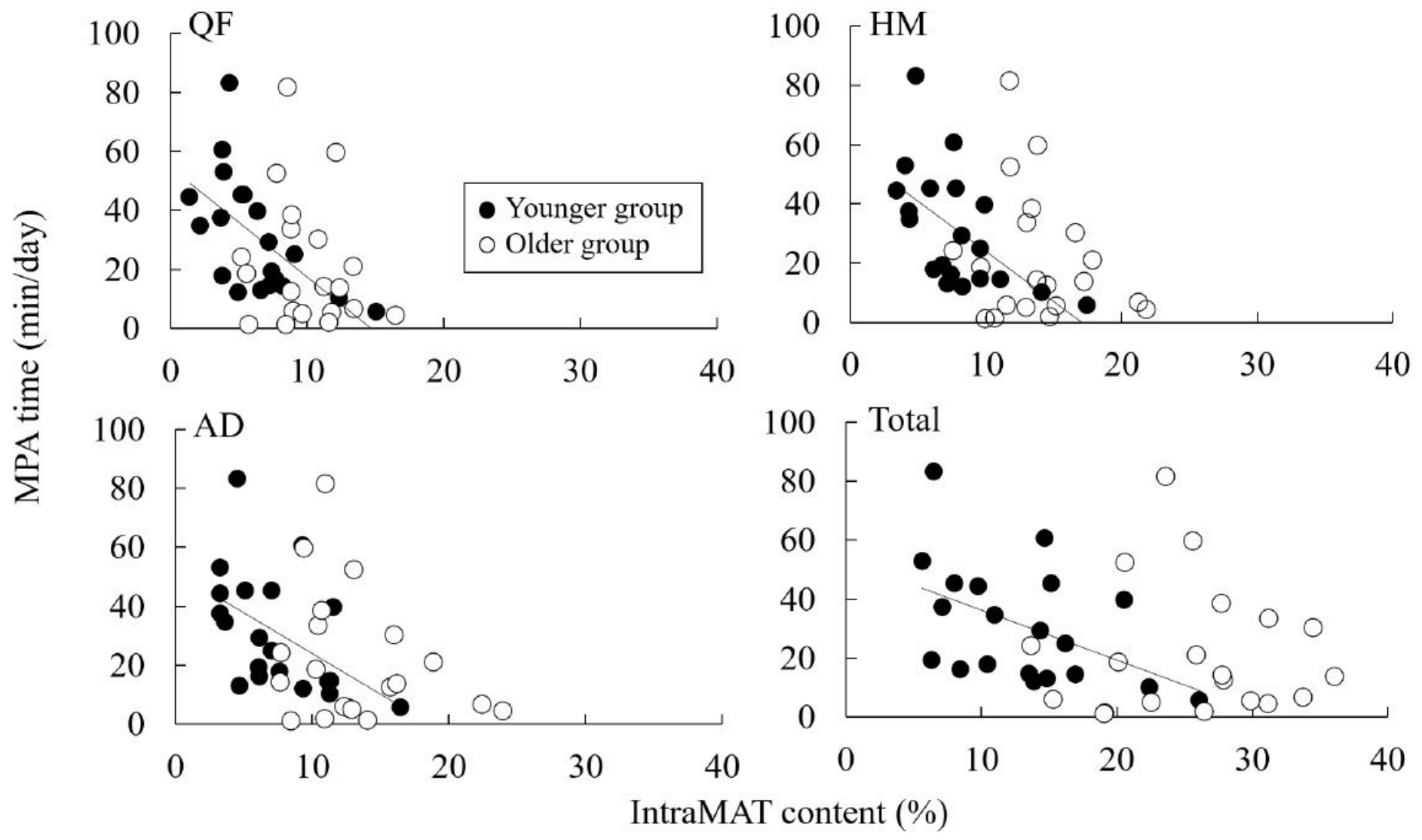

Figure 1

Correlation coefficients between moderate-intensity physical activity (MPA) times and intramuscular adipose tissue (IntraMAT) contents in the younger and older groups. QF quadriceps femoris, AD hip adductors, HM hamstrings. 